\title{
Natural Infection by Leishmania infantum in domestic cats (Felis catus) in a municipality of moderate transmission in the Brazilian semi-arid region
}

\author{
Infecção natural por Leishmania infantum em gatos domésticos (Felis catus) em \\ município de transmissão moderada no semiárido brasileiro
}

\author{
Raizza Barros Sousa Silva1* (1); Roseane de Araújo Portela²; Luís Fernando Batista Arruda²; \\ Jefferson da Silva Ferreira; Erick Platiní Ferreira Souto1; Ana Lucélia de Araújo²; Maria de Fátima Madeira³; \\ Antônio Flávio Medeiros Dantas'; Marcia Almeida de Melo \\ 1 Programa de Pós-graduação em Ciência e Saúde Animal, Unidade Acadêmica de Medicina Veterinária, Universidade Federal de \\ Campina Grande, Patos, PB, Brasil \\ 2 Instituto Federal da Paraíba, São Gonçalo Campus, Sousa, PB, Brasil \\ ${ }^{3}$ Laboratório de Vigilância em Leishmaniose, Instituto de Pesquisa Evandro Chagas, Fundação Oswaldo Cruz (FIOCRUZ), Rio de Janeiro, RJ, Brasil
}

How to cite: Silva RBS, Portela RA, Arruda LFB, Ferreira JS, Souto EPF, Araújo AL, et al. Natural Infection by Leishmania infantum in domestic cats (Felis catus) in a municipality of moderate transmission in the Brazilian semi-arid region. Braz J Vet Parasitol 2020; 29(4): e016620. https://doi.org/10.1590/S1984-29612020102

\begin{abstract}
The main clinical, anatomopathological, and molecular aspects of the infection by Leishmania infantum are described in two cats with multicentric cutaneous, nodular, and ulcerated lesions. The animals were submitted to a clinical examination, followed by serological, molecular and parasitological exams, with culture and isolation of the parasite, and subsequent isoenzymatic characterization. The animals were euthanized and necropsied. Case 1 was an adult, female, mixed-bred stray cat. Case 2 was an adult, male, mixed-bred and domiciled cat. Both were positive for the presence of anti-L. infantum antibodies. In the cytology of the cutaneous nodules and lymph nodes, amastigote forms of Leishmania spp. could be visualized, free and in the interior of the macrophages. In the histopathology, the lesions were characterized by nodular granulomatous and/or ulcerative dermatitis, associated to amastigote forms of Leishmania spp. By means of the polymerase chain reaction, the sequence of the L. infantum kDNA minicircle was amplified. It is concluded that the infection by L. infantum occurs in cats in the State of Paraíba, Northeast region of Brazil and the need to understand the immunological profile of the visceral leishmaniasis in the feline population is highlighted with aimed at the control measures in public health.
\end{abstract}

Keywords: Nodular dermatitis, cats, infection by protozoan, visceral leishmaniasis, zoonosis.

\begin{abstract}
Resumo
Descrevem-se os principais aspectos clínicos, anatomopatológicos e moleculares da infecção por Leishmania infantum em dois gatos, cuja queixa era de lesões cutâneas multicêntricas, nodulares e ulceradas. Os animais foram submetidos à avaliação clínica, seguida de exames sorológicos, molecular e parasitológico, com cultura e isolamento do parasita e posterior caracterização isoenzimática. Os animais foram eutanasiados e encaminhados para a necropsia. O caso 1 era uma gata adulta, sem raça definida e errante. O caso 2 era um gato adulto, sem raça definida e domiciliado. Ambos foram positivos para a presença de anticorpos anti-L. infantum. Na citologia dos nódulos cutâneos e linfonodos, puderam ser visualizadas formas amastigotas de Leishmania spp. livres e no interior de macrófagos. Na histopatologia, as lesões se caracterizavam por dermatite granulomatosa nodular e/ou ulcerativa, associadas a formas amastigotas de Leishmania spp. Por meio da reação em cadeia da polimerase, amplificou-se a sequência do minicírculo do kDNA de L. infantum. Conclui-se que a infecção por $L$. infantum ocorre em gatos no estado da Paraíba, região Nordeste do Brasil. Deve-se ressaltar a necessidade de compreender o perfil imunológico e epidemiológico da leishmaniose visceral na população felina, com vistas às medidas de controle em saúde pública.
\end{abstract}

Palavras-chave: Dermatite nodular, gatos, infecção por protozoário, leishmaniose visceral, zoonose.

Received July 17, 2020. Accepted October 06, 2020

*Corresponding author: Raizza Barros Sousa Silva. E-mail: raizzabss@hotmail.com

This is an Open Access article distributed under the terms of the Creative Commons Attribution License, which permits unrestricted use distribution, and reproduction in any medium, provided the original work is properly cited. 


\section{Introduction}

Leishmaniasis is a complex of diseases caused by the protozoan of the genus Leishmania, that are transmitted by the bite of infected female phlebotomine sand flies. The disease presents in three main forms: visceral, cutaneous and mucocutaneous (WHO, 2017). Several species of wild and domestic animals act as reservoirs (Mancianti, 2004). The domestic dog is considered the main reservoir of visceral leishmaniasis in the urban environment (Solano-Gallego et al., 2009). Domestic cats can also be infected and manifest the disease, but the epidemiology has not been clearly established (Hoogstraal \& Dietlein, 1964); they are capable of infecting sand flies and acting as reservoir hosts (Mendonça et al., 2020).

In cats, the leishmaniasis has already been reported in South America (Bonfante-Garrido et al., 1996), in North America (Trainor et al., 2010), in the Middle East (Solano-Gallego et al., 2007) and in Europe (Grevot et al., 2005; Pocholle et al., 2012). In Brazil, cases have already been described in the States of Minas Gerais (Passos et al., 1996), Rio de Janeiro (Figueiredo et al., 2008), Mato Grosso do Sul (Souza et al., 2009), São Paulo (Costa et al., 2010), Pernambuco (Silva et al., 2014), Mato Grosso (Madruga et al., 2018), Tocantins (Sousa et al., 2019), and Pará (Carneiro et al., 2020). Although the clinical disease is relatively uncommon, the most frequent clinical signs of feline leishmaniasis (FeL) are skin and/or mucocutaneous lesions and lymphadenomegaly caused by species such as Leishmania mexicana, L. venezuelensis, L. braziliensis, L. amazonensis and L. infantum (Bonfante-Garrido et al., 1996; Souza et al., 2009; Pocholle et al., 2012; Pennisi et al., 2015).

Current methods available for the diagnosis of leishmaniasis in dogs are also used for cats, such as serological, cytological and histopathological techniques, culture and molecular methods as polymerase chain reaction (PCR) with the same methodologies (Sampaio et al., 2009; Pennisi et al., 2015; Pennisi \& Persichetti, 2018).

Feline leishmaniasis is an emerging disease, that has been reported in both endemic (Pennisi \& Persichetti, 2018) and non-endemic regions (Spada et al., 2020) and cat may suffer from chronic infection and play the role of additional or secondary reservoir hosts. In order to increase the knowledge about the disease, the objective of this work was to describe the main clinical, cytological, anatomopathological, serological and molecular aspects of the infection by Leishmania infantum in domestic cats (Felis catus) in a Brazilian semiarid region.

\section{Material and Methods}

Two cases of FeL were followed up. The epidemiological (gender, age, breed, origin), clinical and anatomopathological data were obtained from the clinical protocols. The photographic registers were redeemed for the complementation of the description of the lesions. The first case was diagnosed at the Small Animal Medical Clinic of the University Veterinary Hospital Professor Ivon Macêdo Tabosa of the Federal University of Campina Grande (UFCG), in September 2013, and the second case proceeded from the Veterinary Hospital of the Federal Institute of Paraíba (IFPB), in April 2014.

The search for amastigote forms of Leishmania sp. was carried out in the cutaneous lesions and superficial lymph nodes by fine-needle aspiration (FNA). The smears were stained with rapid panoptic staining and observed using a 100x objective on a light microscope.

Blood samples were collected with and without K3- EDTA to perform hemograms and serological assays, respectively. The following hematological parameters were assessed using an automated hematology analyzer (pocH-100iV Diff TM analyzer, Sysmex, São Paulo-SP, Brazil): erythrocyte count, hemoglobin, hematocrit, mean corpuscular volume, mean corpuscular hemoglobin, corpuscular hemoglobin concentration mean, total leukocyte count, platelet count. Blood smears stained with Giemsa (Laborclin Produtos para Laboratórios Ltda., Pinhais-PR, Brazil) were observed with 100X oil immersion lens for the leukocyte differentiation (neutrophils, lymphocytes, eosinophils, basophils, and monocytes count) and the platelet count.

As there are no standardized commercial serological tests for the feline specie, the serological diagnose was done by both Dual Path Platform rapid immunochromatographic test (TR DPP® LVC, Bio-Manguinhos, Oswaldo Cruz Foundation, Rio de Janeiro-RJ, Brazil) and the ELISA S7 ${ }^{\circledR}$ immunoenzymatic assay (Biogene Indústria e Comércio Ltda., Recife-PE, Brazil) standardized for canine specie, following the manufacturers' recommendations.

The cats were euthanized following the Guidelines of Good Practices in Animal Euthanasia (CFMV, 2012), and sent to the Laboratory of Animal Pathology of the UFCG. During the necropsy, fragments of the main organs were harvested for diverse tests. Fragments of the skin, lymph nodes, central nervous system, and organs from the 
thoracic and abdominal cavities were fixed in $10 \%$ buffered formalin, routinely processed, embedded in paraffin wax, cut at $3 \mu \mathrm{m}$, and stained with hematoxylin and eosin (HE).

Fragments of the liver, spleen, bone marrow, lymph node and cutaneous lesions from one of the cats were cultivated in biphasic NNN culture medium (NNN sheep blood agar), as described by Nicole, Novy and Neal (Novy \& McNeal, 1904), and LIT (Liver Infusion Tryptose). The tubes were maintained in a Biochemical Oxygen Demand (B.O.D.) chamber at $22^{\circ} \mathrm{C}$. The culture was examined in an optical microscope with 40X lens, and subcultivated every 12 days up to day 30 , to observe the promastigote.

After the isolation, the isoenzymatic characterization was performed in the Leishmaniasis Surveillance Laboratory, Evandro Chagas Research Institution, Oswaldo Cruz Foundation (FIOCRUZ), in Rio de Janeiro. The isolated promastigotes were characterized by Multilocus Enzime Electrophoresis (MLEE). The MLEE was carried out in $1 \%$ agarose gel as described by Cupolillo et al. (1994). Five enzymatic systems were used: Glucose-6-phosphate dehydrogenase (G6PDH, EC.1.1.1.49), 6-phosphogluconate dehydrogenase (6PGDH, EC.1.1.1.43), glucose phosphate isomerase (GPI, EC.5.3.1.9), nucleoside hydrolase ( $\mathrm{NH}, \mathrm{EC}$. 3.2.2.1) and malic enzyme (ME, EC.1.1.1.40). The gels were analyzed by determination of the electrophoretic mobility of the bands, based on standard positions of reference of the samples of Leishmania infantum (MHOM/BR/74/PP75) and Leishmania braziliensis (MHOM/BR/75/M2903) obtained from the collection of the Oswaldo Cruz Institute (IOC)/ FIOCRUZ.

The same tissues from both cats and whole blood were subjected to the DNA extraction to perform the Polymerase Chain Reaction (PCR). The DNA extraction was carried out using Brazol ${ }^{\circledR}$ reagent (LGC Biotecnologia Ltda., Cotia-SP, Brazil), following the manufacturer's recommendations. Leishmania infantum DNA was obtained from parasite maintained in LIT and was used as positive control of the PCR. The parasites were previously isolated of positive dog by serologic test and characterized by the isoenzyme profile at the Leishmaniasis Surveillance

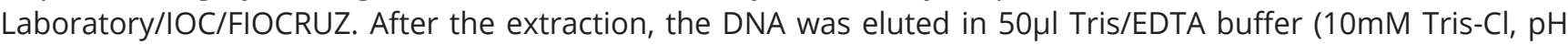
7.5 and $1 \mathrm{mM}$ of EDTA, pH 8.0) and the concentration was measured using a spectrophotometer (Eppendorf BioPhotometer ${ }^{\circledR}$ plus, Hamburg, Germany). For the amplification of the sequence of the L. infantum kDNA minicircle were used the initiators LINR4 (5'-GGGGTTGGTGTAAAATAGGG-3') and LIN19 (5'-CAGAACGCCCCTACCCG-3'), which amplified the product of 720 base pairs (Aransay et al., 2000). The amplification reaction followed the protocol detailed by Silva et al. (2016).

\section{Results}

Two cats (Felis catus) from the municipality of Sousa, Paraíba, Northeast of Brazil, that presented multicentric cutaneous lesions, were taken to the Veterinary Hospitals of UFCG and the IFPB.

Animal 1 was an adult, mongrel female cat, that presented nodular and non-ulcerated lesions on the extremities of the ears, snout and lips (upper and lower) and right lower eyelid, measuring from 0.3 to $1.5 \mathrm{~cm}$ of diameter (Figure 1A). There were still non-ulcerated and nodular lesions on the dorsum, on the extremity of the tail and thoracic limbs in the metacarpal region, and an enlargement of the submandibular, prescapular and popliteal lymph nodes.

Animal 2 was an adult, mongrel male cat, with a guardian, which presented a bad corporal condition, dehydration, opaque and damaged fur, breathing difficulty and nodular non-ulcerated lesions on the extremities of the ears, snout and left eyelid measuring from 0.3 to $1.0 \mathrm{~cm}$ of diameter. There were still non-nodular and ulcerated lesions on the thoracic limbs (Figure 1B).

Cytological examination of cutaneous lesions and superficial lymph nodes revealed numerous either roundor oval-shaped organisms with a basophilic nucleus and kinetoplast near to the nucleus, compatible with amastigotes of Leishmania sp. The amastigote forms were visualized both free and in the cytoplasm of macrophages (Figures 1C and 1D).

Macroscopically, the nodular lesions were smooth, homogeneous and yellowish-with at cut (Figures 2A and 2B). In animal 1, the liver and spleen were enlarged (hepatosplenomegaly) and the submandibular, subscapular and popliteal lymph nodes were enlarged (lymphadenomegaly) and with loss of the corticomedullary distinction. In case 2 , the mediastinal lymph nodes were enlarged.

In the histopathology, in both cases, the lesions were characterized by accentuated nodular and/or ulcerative granulomatous dermatitis, associated to intralesional amastigotes of Leishmania sp. The thickening of the superficial and profound dermis was observed by inflammatory infiltrate of macrophages, occasional multinucleated giant 


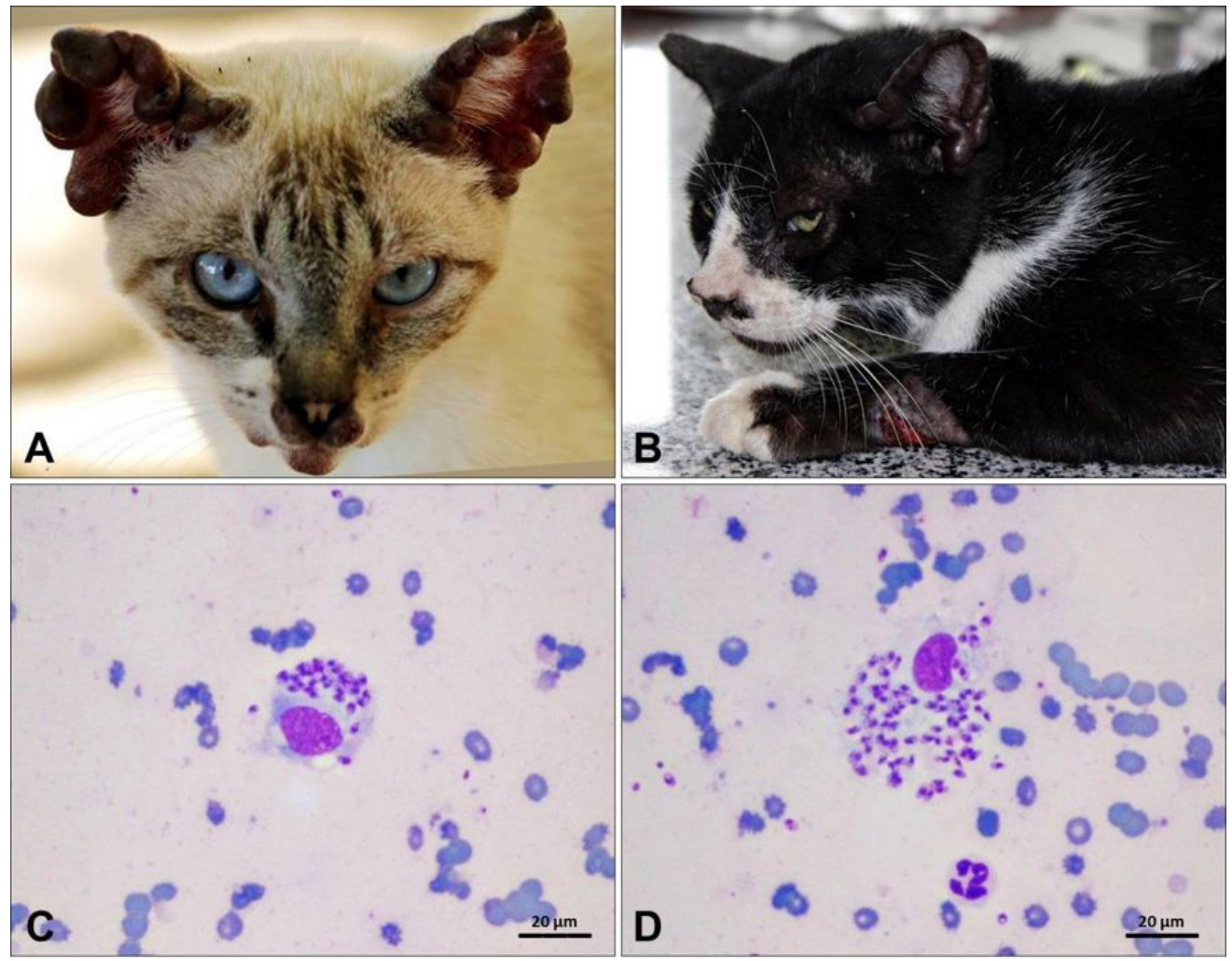

Figure 1. Feline leishmaniasis. A) Case1. Nodular lesions in the extremities of the ears, snout, lips, right lower eyelid. B) Case 2. Nodular lesions on the extremities of the ears and ulcerated on the left thoracic limb. C) Amastigotes of Leishmania infantum in the interior of the macrophage. Rapid panoptic. Obj. 40x. D) Free amastigotes of Leishmania infantum. Rapid panoptic. Obj. 40x.

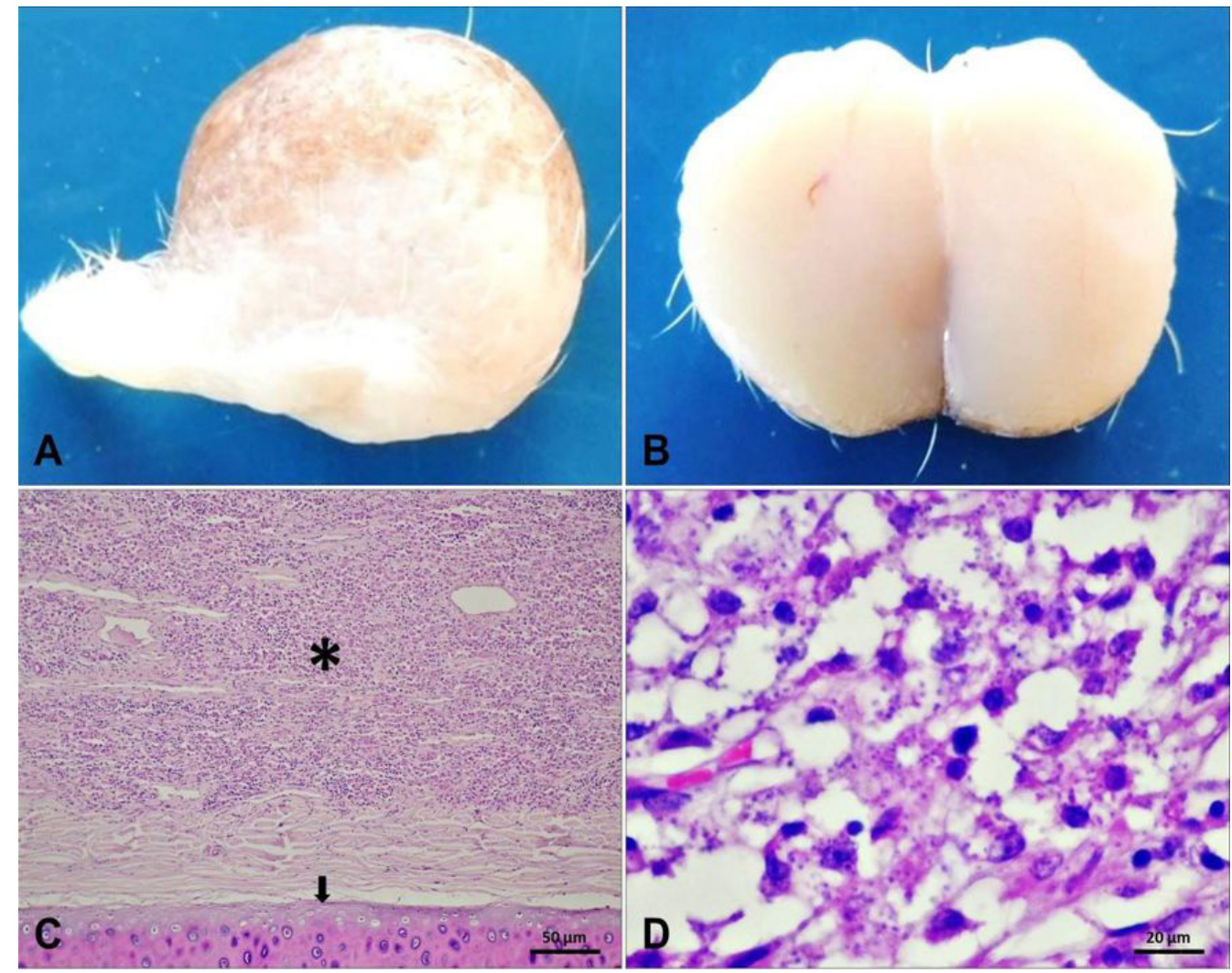

Figure 2. Feline leishmaniasis. A) Cutaneous nodule in the auricular region. B) At cutting, the nodule exhibiting a homogeneous and yellowish-white surface. C) Thickening of the superficial and profound dermis by predominantly histiocytic inflammatory infiltrate (asterisk) in the auricular region (arrow, auricular cartilage). HE. Obj. 40x. D) Innumerous amastigotes of Leishmania infantum in the midst of the inflammatory reaction. HE. Obj. 40x. 
cells and rare lymphocytes, plasmocytes and Mott cells (Figure 2C). The macrophages and giant cells were filled with basophilic organisms, measuring from 2-4 $\mu \mathrm{m}$ in diameter, varying from round to oval-shaped and, sometimes, surrounded by a clear halo. These structures were also visualized free in the interstice, isolated or forming agglomerates, and were morphologically compatible with amastigote forms of Leishmania sp. (Figure 2D). There was still discreet fibroplasia and neovascularization in the midst of the inflammatory reaction. In some lesions, it was possible to observe multifocal areas of ulceration and necrosis of the overlaying epidermis.

In the lymph nodes, there was and accentuated infiltrate of macrophages and plasmocytes, with occasional multinucleated giant cells and Mott cells, extending from the cortical to the medullary region, causing a distention of the medullary cords. It was also observed macrophages filling the lumen of the medullary sinusoids (sinusoidal histiocytosis) and follicular lymphoid hyperplasia with individual necrosis of some lymphocytes in the germinative centers. In the spleen, there was a moderate quantity of macrophages in the white pulp and presence of Mott cells.

In case 1, inflammatory infiltrate of macrophages, lymphocytes and plasmocytes was verified in the periportal region of the liver. In the kidneys, there was the formation of discreet granulomas and occasional presence of Mott cells in the cortical region. The bone marrow was hypercellular, with a large quantity of histiocytes and hematopoietic precursors, and accentuated reduction of the adipose tissue. It was possible to identify the amyloid deposition, by means of Congo red stain, in the perisinusoidal spaces of the liver, medullary region of the kidney and in the white and red pulps of the spleen, especially in the membranes of the vessels and blood capillaries. In all these organs, the macrophages and the multinucleated giant cells exhibited distended cytoplasm by innumerous amastigote forms of Leishmania sp.

By PCR, there was amplification of the product of 720 base pairs in the samples from bone marrow, whole blood, spleen, liver, lymph nodes and skin lesions of both cats, corresponding to the Leishmania infantum kDNA minicircle sequence flanked by the primers LINR4 and LIN19 (Supplementary Material Figure S1). Promastigote forms of Leishmania sp. were isolated by the culture of bone marrow, liver, spleen, lymph node and cutaneous nodule aspirations from Animal 1. By multilocus enzyme electrophoresis technique, the promastigote forms were characterized as L. infantum.

In both cases, the hemograms evidenced discreet neutrophilia with shift to the right, both were positive for the presence of antibodies against the $\mathrm{K} 28$ recombinant antigen of the rapid test DPP ${ }^{\circledR}$ and against the HSP70 recombinant protein of the ELISA S7 $®$ kit.

\section{Discussion}

The canine visceral leishmaniasis has already been reported in several municipalities in Paraíba (Silva et al., 2016; Fernandes et al., 2016; Silva et al., 2018). According to the DATASUS, from 2010 to 2018 were notified and confirmed 33 cases of autochthone human visceral leishmaniasis in Sousa-PB, however, this is the first report of feline visceral leishmaniasis in Paraíba. The municipality of Sousa is located in the intermediary geographical region of Sousa-Cajazeiras, immediate region to Sousa, in the West of the State of Paraíba, $438 \mathrm{~km}$ distance from João Pessoa, the State's capital city. The predominant vegetation is hyper-xerophile caatinga, without leaves in the dry season, with abundance of cacti and small-sized plants. The climate is semi-arid tropical, with average annual temperature of $26.7^{\circ} \mathrm{C}$ and average annual precipitation of 872 millimeters $(\mathrm{mm})$, concentrated between January and April, and March is the month with the greatest precipitation $(227 \mathrm{~mm})$. These conditions are propitious for the maintenance of the vector, Lutzomyia longipalpis. In Mossoró, Rio Grande do Norte, where the predominant vegetation is also hyper-xerophile caatinga, the highest prevalence of the phlebotomine occurred during the rainy season (Amóra et al., 2010). Costa et al. (2013) observed an increase in the collection of specimens of Lutzomyia longipalpis in months in which the humidity was above $75 \%$.

The animals presented nodular lesions on the skin, rich in intra and extracellular parasites and, in the serological diagnosis, were positive in the ELISA S7 $®$ and in the DPP $®$. In dogs with skin lesions and enlarged lymph nodes, normally, the serology is positive in the ELISA S7 $®$ and in the DPP $®$. In Brazil, the L. infantum has already been reported in cats in endemic regions for canine visceral leishmaniasis and, animals with isolation of parasites in tissues, were negative in the serology and did no present skin lesions (Costa et al., 2010; Vides et al., 2011; Sobrinho et al., 2012). This fact may occur as a result of the time difference in the humoral response; the production of antibodies may be precocious or late according to the antigen.

Due to the lack of standardized commercial serological tests for the diagnose of feline visceral leishmaniasis, ELISA S7 ${ }^{\circ}$ and TR DPP ${ }^{\circledR}$ were used to evaluate the disease in that specie and showed to be able of detecting 
antibodies in the feline species. However, studies are needed to determine the accuracy of these techniques in the diagnosis of FeL and the combination of different diagnostic techniques is recommended to decrease the chance of erroneous results, since these techniques, even in the canine species, present different sensitivities and specificities; discrepancies that can be influenced by many factors (Silva et al., 2016; Pennisi \& Persichetti, 2018).

The PCR was positive in all the analyzed tissues. Similar result was found by Sousa et al. (2019), who analyzed blood samples, conjunctiva, spleen, liver, lymph nodes, skin, lung, and kidney from a two-month old cat. AlvesMartin et al. (2017), using the same primers as in the present study, detected 9.1\% of whole blood positive samples, including animals with and without symptoms. On the other hand, Bezerra et al. (2019) and Coura et al. (2018), in studies carried out in Brazilian endemic regions for leishmaniasis, did not detect any positive samples by PCR, even in cats that are reactive in serology.

The non-ulcerated nodulations on the extremity of the ears, eyelids and snout were observed in both felines. These diffuse nodulations on the ear were found by Bonfante-Garrido et al. (1996) in one of four cats reported. The other characteristics of the clinical lesions were similar to other reports of leishmaniasis in cats (BonfanteGarrido et al., 1996; Souza et al., 2009; Trainor et al., 2010; Pennisi et al., 2015; Alves-Martin et al., 2017). There are reports that no clinical sign was observed in serologically positive felines (Costa et al., 2010; Bresciani et al., 2010; Alves-Martin et al., 2017). In other words, in cats, the symptomatology may present a similar course to the visceral leishmaniasis in dogs, going from apparently healthy animals, passing by oligosymptomatic, up to severe stages of the disease (Akhtardanesh et al., 2017; Gontijo \& Melo, 2004). The infection by L. infantum may also be associated to the infection by feline retrovirus or other immunosuppressive diseases (Grevot et al., 2005).

The visualization of the amastigote forms of the aspirates of the lesions and/or lymph nodes was positive for the majority of the reports in symptomatic cats (Bonfante-Garrido et al., 1996; Souza et al., 2009; Bresciani et al., 2010; Sousa et al., 2019) and, as in the dogs, the lesions seem to be due to the immune response against the parasites (Hervás et al., 2001). However, the negative cytological test of the bone marrow, spleen and live has already been reported (Grevot et al., 2005). Costa et al. (2010), in a serological and parasitological survey in cats living in endemic region for canine visceral leishmaniasis, observed that, of the 23 (11.50\%) positive animals in the serology, only two were positive in the cytology. In the same study, another six cats were positive in cytology and non-reactive in serology, totaling eight positive cats: in four cats, the amastigotes were visualized in the popliteal lymph node; in one in the liver; in another in the popliteal lymph node and in the bone marrow, and in two other cases the parasites were visualized in the popliteal lymph node, spleen and bone marrow.

Among the macroscopic findings, Grevot et al. (2005) also observed a moderate enlargement of the spleen and diffuse hypertrophy of the white pulp in a feline with skin lesion, and Costa et al. (2010), despite mentioning hepatosplenomegaly in two seropositive cats, did not affirm that this was as a result of the infection by Leishmania. According to Feitosa et al. (2000), the leishmania species multiply in macrophages of the liver and spleen, eventually producing hepatosplenomegaly, and, generally a hepatitis, which is frequently observed in dogs with visceral leishmaniasis.

Histologically, the lesions in the dermis are similar and Always associated to the presence of amastigote forms, either intracellular or in the interstice, or presenting another concomitant pathology (Grevot et al., 2005; Trainor et al., 2010). In this work, was reported the presence of Mott cells and multinucleated giant cells in the dermis, lymph node and spleen. The presence of the Mott cells is due to the excessive protein production (immunoglobulins) in chronic infections (McGavin \& Zachary, 2013), described in felines with B-cell lymphomas (Kanehara et al., 2016), but already observed in dogs with visceral leishmaniasis (Lima et al., 2015). Another particular finding described here are the renal, splenic and hepatic amyloidosis lesions found in Case 1. Grevot et al. (2005) found lesions of discreet hepatic fibrosis and hyalinosis of the central vein, membranous glomerulonephritis, in addition to inflammatory infiltrate in the parotid gland and intestine. It is suggested that the amyloidosis reported in the present article should be further clarified, as it may occur due to other infections or chronic inflammatory conditions. It may be due to immunogenic amyloid, due to the production of large amounts of antibody light chains and their fragments, a hypothesis reinforced by the presence of Mott cells.

Finally, it may be concluded that the infection by Leishmania infantum occurs in cats in the State of Paraíba, Northeast region of Brazil. However, there are no control measures indicated when the cat is stricken by the infection. Therefore, it is highlighted the need to better understand the immunological and epidemiological profile of the visceral leishmaniasis in the feline population with a view to public health. It is recommended the inclusion of this disease as differential diagnosis in the feline species. 


\section{Acknowledgements}

We are grateful to the Veterinary Hospitals of the UFCG and the IFPB and to the FIOCRUZ for the support for the development of this work.

To the Coordination for the Improvement of Higher-Level Personnel (CAPES) for the study grant.

\section{References}

Akhtardanesh B, Sharifi I, Mohammadi A, Mostafavi M, Hakimmipour M, Pourafshar NG. Feline visceral leishmaniasis in Kerman, southeast of Iran: serological and molecular study. J Vector Borne Dis 2017; 54(1): 96-102. PMid:28352052.

Alves-Martin MF, Paixão MS, Silva DT, Tenório MS, Alves ML, Starke-Buzetti WA, et al. Detection of Leishmania spp. using parasitological, serological and molecular assays in asymptomatic and sick cats from an endemic area of visceral leishmaniosis in Brazil. Asian Pac J Trop Dis 2017; 7(11): 659-664. http://dx.doi.org/10.12980/apjtd.7.2017D7-100.

Amóra SSA, Bevilaqua CML, Dias EC, Feijó FMC, Oliveira PGM, Peixoto GCX, et al. Monitoring of Lutzomyia longipalpis Lutz \& Neiva, 1912 in area of intense transmission of visceral leishmaniasis in Rio Grande do Norte, Northeast Brazil. Rev Bras Parasitol Vet 2010; 19(1): 39-43. http://dx.doi.org/10.1590/S1984-29612010000100008. PMid:20385058.

Aransay AM, Scoulica E, Tselentis Y. Detection and identification of Leishmania DNA within naturally infected sand flies by seminested PCR on minicircle kinetoplastic DNA. J Appl Environ Microbiol 2000; 66(5): 1933-1938. http://dx.doi.org/10.1128/ AEM.66.5.1933-1938.2000. PMid:10788363.

Bezerra JAB, Oliveira IVPM, Yamakawa AC, Nilsson MG, Tomaz KLR, Oliveira KDS, et al. Serological and molecular investigation of Leishmania spp. infection in cats from an area endemic for canine and human leishmaniasis in Northeast Brazil. Braz J Vet Parasitol 2019; 28(4): 790-796. http://dx.doi.org/10.1590/s1984-29612019082. PMid:31691733.

Bonfante-Garrido R, Valdivia O, Torrealba J, García MT, Garófalo MM, Urdaneta I, et al. Cutaneous leishmaniasis in cats (Felis domesticus) caused by Leishmania (Leishmania) venezuelensis. Rev Científica FCV-LUZ 1996; 6(3): 187-190.

Bresciani KDS, Serrano ACM, Matos LVS, Savani ESMM, D'Auria SRN, Perri SHV, et al. Ocorrência de Leishmania spp. em felinos do município de Araçatuba, SP. Rev Bras Parasitol Vet 2010; 19(2): 127-129. http://dx.doi.org/10.1590/S1984-29612010000200012. PMid:20624352.

Carneiro LA, Vasconcelos Dos Santos T, Lima LVR, Ramos PKS, Campos MB, Silveira FT. First report on feline leishmaniasis caused by Leishmania (Leishmania) amazonensis in Amazonian Brazil. Vet Parasitol Reg Stud Rep 2020; 19: 100360. http://dx.doi. org/10.1016/j.vprsr.2019.100360. PMid:32057387.

Conselho Federal de Medicina Veterinária - CFMV. Guia brasileiro de boas práticas em eutanásia em animais - Conceitos e procedimentos recomendados $1^{\circ}$ ed. [online]. Brasília: CFMV; 2012. 62 p. [cited 2019 Jan 10]. Available from: http://portal.cfmv. gov.br/uploads/files/Guia\%20de\%20Boas\%20Pr\%C3\%A1 ticas\%20para\%20Eutanasia.pdf.pdf

Costa PL, Dantas-Torres F, da Silva FJ, Guimarães VC, Gaudêncio K, Brandão-Filho SP. Ecology of Lutzomyia longipalpis in an area of visceral leishmaniasis transmission in north-eastern Brazil. Acta Trop 2013; 126(2): 99-102. http://dx.doi.org/10.1016/j. actatropica.2013.01.011. PMid:23369878.

Costa TAC, Rossi CN, Laurenti MD, Gomes AAD, Vides JP, Sobrinho LSV, et al. Occurrence of leishmaniasis in cats from endemic area for visceral leishmaniasis. Braz JVet Res Anim Sci 2010; 47(3): 213-217. http://dx.doi.org/10.11606/issn.1678-4456.bjvras.2010.26858.

Coura FM, Passos AKP, Pelegrino MOF, Leme FOP, Paz GF, Gontijo CMF, et al. Serological, molecular, and microscopic detection of Leishmania in cats (Felis catus) in Belo Horizonte, Minas Gerais State, Brazil. Braz J Vet Parasitol 2018; 27(4): 570-574. http:// dx.doi.org/10.1590/s1984-296120180052. PMid:30183999.

Cupolillo E, Grimaldi G Jr, Momen H. A general classification of new world Leishmania using numerical zymotaxonomy. Am J Trop Med Hyg 1994; 50(3): 296-311. http://dx.doi.org/10.4269/ajtmh.1994.50.296. PMid:8147488.

Feitosa MM, Ikeda FA, Luvizotto MCR, Perri SHV. Aspectos clínicos de cães com leishmaniose visceral no município de Araçatuba, São Paulo (Brasil). Clin Vet 2000; 5(28): 36-44.

Fernandes ARF, Pimenta CLRM, Vidal IF, Oliveira GC, Sartori RS, Araújo RB, et al. Risk factors associated with seropositivity for Leishmania spp. and Trypanosoma cruzi in dogs in the state of Paraiba, Brazil. Rev Bras Parasitol Vet 2016; 25(1): 90-98. http:// dx.doi.org/10.1590/S1984-29612016010. PMid:26982555.

Figueiredo FB, Pereira SA, Gremião IDF, Nascimento LD, Madeira MF, Schubach TMP. Leishmaniose tegumentar americana em gato doméstico no município do Rio de Janeiro, Brasil - relato de caso. Rev Clin Vet 2008; 74: 58-60.

Gontijo CMF, Melo MN. Leishmaniose Visceral no Brasil: quadro atual, desafios e perspectivas. Rev Bras Epidemiol 2004; 7(3): 338-349. http://dx.doi.org/10.1590/S1415-790X2004000300011. 
Grevot A, Jaussaud Hugues P, Marty P, Pratlong F, Ozon C, Haas P, et al. Leishmaniosis due to Leishmania infantum in a FIV and FelV positive cat with a squamous cell carcinoma diagnosed with histological, serological and isoenzymatic methods. Parasite 2005; 12(3): 271-275. http://dx.doi.org/10.1051/parasite/2005123271. PMid:16218216.

Hervas J, Chacon-Manrique de Lara F, LopezJ, Moreno A, Guerrero M-J, Gomez-Villamandos JC. Granulomatous (pseudotumoral) iridociclitis associated with leishmaniasis in a cat. Vet Rec 2001; 149(20): 624-625. http://dx.doi.org/10.1136/vr.149.20.624. PMid:11761295.

Hoogstraal H, Dietlein DR. Leishmaniasis in the Sudan Republic: Recent results. Bull World Health Organ 1964; 31(1): 137-143. PMid:14230887.

Kanehara T, Matsui N, Murakami M, Maruo K, Mori T, Hirata A, et al. B-cell lymphoma with Mott cell differentiation in a cat. Vet Clin Pathol 2016; 45(2): 356-360. http://dx.doi.org/10.1111/vcp.12343. PMid:26951888.

Lima AMV, Santos AS, Faleiro MBR, Moura VMBD, Brito FLC, Brito LAB. Imunomarcação de Leishmania sp. e aspectos histológicos na terceira pálpebra de cães naturalmente infectados por Leishmania (Leishmania) chagasi. Cienc Anim Bras 2015; 16(4): 538-547. http://dx.doi.org/10.1590/1089-6891v16i426859.

Madruga G, Ribeiro AP, Ruiz T, Sousa VRF, Campos CG, Almeida ABPF, et al. Ocular manifestations of leishmaniasis in a cat: first case report from Brazil. Arq Bras Med Vet Zootec 2018; 70(5): 1514-1520. http://dx.doi.org/10.1590/1678-4162-9244.

Mancianti F. Leishmaniosi felina: quale ruolo epidemiologico? Parassitologia 2004; 46(1-2): 203-206. PMid:15305717.

McGavin MD, Zachary JF. Bases da Patologia em Veterinária. 5th ed. Rio de Janeiro: Elsevier; 2013.

Mendonça IL, Batista JF, Lopes KSPDP, Magalhães FDCR No, Alcântara DS, Merigueti YFFB, et al. Infection of Lutzomyia longipalpis in cats infected with Leishmania infantum. Vet Parasitol 2020; 280: 109058. http://dx.doi.org/10.1016/j.vetpar.2020.109058. PMid:32200198.

Novy FG, McNeal WJ. On the cultivation of Trypanosoma brucei.J Infect Dis 1904; 1(1): 1-30. http://dx.doi.org/10.1093/infdis/1.1.1.

Passos VMA, Lasmar EB, Gontijo CMF, Fernandes O, Degrave W. Natural infection of a domestic cat (Felis domesticus) with Leishmania (Viannia) in the Metropolitan Region of Belo Horizonte, State of Minas Gerais, Brazil. Mem Inst Oswaldo Cruz 1996; 91(1): 19-20. http://dx.doi.org/10.1590/S0074-02761996000100003. PMid:8734945.

Pennisi M, Cardoso L, Baneth G, Bourdeau P, Koutinas A, Miró G, et al. LeishVet: update and recommendations on feline leishmaniosis. Parasit Vectors 2015; 8(1): 302. http://dx.doi.org/10.1186/s13071-015-0909-z. PMid:26041555.

Pennisi MG, Persichetti MF. Feline leishmaniosis: is the cat a small dog? Vet Parasito/2018; 251: 131-137. http://dx.doi.org/10.1016/j. vetpar.2018.01.012. PMid:29426470.

Pocholle E, Reyes-Gomez E, Giacomo A, Delaunay P, Hasseine L, Marty P. A case of feline leishmaniasis in the south of France. Parasite 2012; 19(1): 77-80. http://dx.doi.org/10.1051/parasite/2012191077. PMid:22314243.

Sampaio RNR, Gonçalves MC, Leite VA, França BV, Santos G, Carvalho MSL, et al. Estudo da transmissão da leishmaniose tegumentar americana no Distrito Federal. Rev Soc Bras Med Trop 2009; 42(6): 686-690. http://dx.doi.org/10.1590/S003786822009000600015. PMid:20209356.

Silva RBS, Mendes RS, Santana VL, Souza HC, Ramos CPS, Souza AP, et al. Aspectos epidemiológicos da leishmaniose visceral canina na zona rural do semiárido paraibano e análise de técnicas de diagnóstico. Pesq Vet Bras 2016; 36(7): 625-629. http:// dx.doi.org/10.1590/S0100-736X2016000700011.

Silva RBS, Porto ML, Barbosa WO, Souza HC, Marques NFSP, Azevedo SS, et al. Seroprevalence and risk factors associated with canine visceral leishmaniasis in the State of Paraíba, Brazil. Rev Soc Bras Med Trop 2018; 51(5): 683-688. http://dx.doi. org/10.1590/0037-8682-0429-2017. PMid:30304279.

Silva RC, Ramos RA, Pimentel DS, Oliveira GM, Carvalho GA, Santana MA, et al. Detection of antibodies against Leishmania infantum in cats (Felis catus) from the State of Pernambuco, Brazil. Rev Soc Bras Med Trop 2014; 47(1): 108-109. http://dx.doi. org/10.1590/0037-8682-0005-2012. PMid:24603746.

Sobrinho LSV, Rossi CN, Vides JP, Braga ET, Gomes AA, De Lima VM, et al. Coinfection of Leishmania chagasi with Toxoplasma gondii, Feline Immunodeficiency Virus (FIV) and Feline Leukemia Virus (FeLV) in cats from an endemic area of zoonotic viscera leishmaniasis. Vet Parasitol 2012; 187(1-2): 302-306. http://dx.doi.org/10.1016/j.vetpar.2012.01.010. PMid:22285010.

Solano-Gallego L, Koutinas A, Miró G, Cardoso L, Pennisi MG, Ferrer L, et al. Directions for the diagnosis, clinical staging, treatment and prevention of canine leishmaniosis. Vet Parasito/ 2009; 165(1-2): 1-18. http://dx.doi.org/10.1016/j.vetpar.2009.05.022. PMid:19559536.

Solano-Gallego L, Rodríguez-Cortés A, Iniesta L, Quintana J, Pastor J, Espada Y, et al. Cross-sectional serosurvey of feline leishmaniasis in ecoregions around the Northwestern Mediterranean. Am J Trop Med Hyg 2007; 76(4): 676-680. http://dx.doi. org/10.4269/ajtmh.2007.76.676. PMid:17426169. 
Sousa SAP, Santos HD, Carvalho CA, Machado AM, Oliveira LE, Ribeiro TMP, et al. Acute visceral leishmaniasis in a domestic cat (Felis silvestris catus) from the state of Tocantins, Brazil. Semina: Ciênc Agrár 2019; 40(4): 1723-1730. http://dx.doi.org/10.5433/16790359.2019v40n4p1723.

Souza Al, Nunes VLB, Borralho VM, Ishikawa EAY. Domestic feline cutaneous leishmaniasis in the municipality of Ribas do Rio Pardo, Mato Grosso do Sul state, Brazil: a case report. J Venom Anim Toxins Incl Trop Dis 2009; 15(2): 359-365. http://dx.doi. org/10.1590/S1678-91992009000200017.

Spada E, Perego R, Vitale F, Bruno F, Castelli G, Tarantola G, et al. Feline Leishmania spp. Infection in a Non-endemic area of Northern Italy. Animals (Basel) 2020; 10(5): 817. http://dx.doi.org/10.3390/ani10050817. PMid:32397321.

Trainor KE, Porter BF, Logan KS, Hoffman RJ, Snowden KF. Eight cases of feline cutaneous leishmaniasis in Texas. Vet Patho/ 2010; 47(6): 1076-1081. http://dx.doi.org/10.1177/0300985810382094. PMid:20826847.

Vides JP, Schwardt TF, Sobrinho LSV, Marinho M, Laurenti MD, Biondo AW, et al. Leishmania chagasi infection in cats with dermatologic lesions from an endemic area of visceral leishmaniosis in Brazil. Vet Parasitol 2011; 178(1-2): 22-28. http://dx.doi. org/10.1016/j.vetpar.2010.12.042. PMid:21282011.

World Health Organization - WHO. Global leishmaniasis update, 2006-2015: A turning point in leishmaniasis surveillance. Weekly Epidemiological Record 2017;38:557-65. [cited 2020 Jan 10]. Available from: http://apps.who.int/iris/bitstream/10665/258974/1/ WER9238-557-565.pdf 


\section{Supplementary Material}

Supplementary material accompanies this paper.

Figure S1. Polymerase Chain Reaction results of tissues infected with L. infantum obtained from a cat. 1.5\% agarose gel stained with Blue Green (LGC Biotecnologia). MW = Molecular weight; NC = negative control; $\mathrm{PC}=$ positive control; $\mathrm{B}=$ blood; $\mathrm{BM}=$ bone marrow; $\mathrm{LN}=$ lymph node; $\mathrm{L}=$ liver; $\mathrm{S}=$ spleen; $\mathrm{CL}=$ cutaneous lesions.

This material is available as part of the online article from http://www.scielo.br/rbpv 